\section{Being black in South Africa}

SIR-G. Osthoff (Nature 343, 110; 1990) wishes to convince us that the educational prospects of South African non-whites are not disadvantaged by the political system they live in, but are disadvantaged by their culture. Moreover, he wishes to attribute similar causes to the lower levels of black American enrolment in higher education in the United States partly by raising the issues together.

Leaving aside the different motivations of different populations and the priority given to higher education in different communities, his thesis represents a popular position among Afrikaaners and their English-speaking apologists in justifying the current allocation of funds to the education of blacks in South Africa. This thesis has many defects. First, South African tribal blacks are introduced to English and Afrikaans at a relatively advanced age so they must make a linguistic reorientation as their later tuition is not done in their native languages. Separation of schools could be justified on a linguistic basis but the decision to institute a linguistic reorientation cannot be a cultural one. Furthermore, no native-born white child in South Africa has this limitation. A curious irony of this system is that Afrikaner children were considered to be the class dunces before Afrikaner nationalism because a powerful political force and when Afrikaans and, earlier, Dutch were forbidden in classrooms. Memories of such treatment still provide much bitterness among Afrikaners.

Second, South African blacks are technically not citizens and so are sequestered to 'homelands'. Moreover, they may not live where they choose nor can they own property, and they are unlikely to earn sufficient money to be able to send their children to the schools of their own choosing. Again, these are not cultural aspects of their lives but constitute part of the legislation of South Africa.

Third, most South African blacks do not pay much tax because they do not earn much money: they are not paid equal wages for equal work. Indeed, they cannot rise to the level of their own competence because they are generally not hired under principles of equal opportunity for work which is more than semi-skilled. Under these circumstances, what incentive is there for black South Africans to go to university to study mathematics when they would have little or no expectation of being employed? Most are so affected by the hopelessness of their political situation that to spend three or more years at a university instead of trying to earn what meagre wage they can to survive is seen as a gross waste of time.

My own experience of South Africa is not that of a journalist, visitor or immi-

\section{Letters from America}

grant, but that of a South African who went through the non-white educational system. It was only by emigrating from South Africa that I could pursue a professional career in science.

Finally, does anyone see the relevance of the kinds of sport that South Africa blacks pursue and what relevance does all this have for black Americans?

WILLIAM BARENDSE CSIRO Tropical Cattle Research Centre, Box 5545,

Rockhampton Mail Centre,

Queensland 4702, Australia

SIR-Benatar's Commentary on a selective academic boycott of South Africa (Nature 343, 505; 1990) could hardly have appeared at a better time. The recent changes in the country are enough to reopen this question among even the most determined advocates of the boycott, but the opportunity for some relaxation had already appeared. The African National Congress has approved of the Union of Democratic University Staff Associations (UDUSA) and has itself resolved "to encourage and promote academic exchanges to advance scholarship in teaching and research, provided these exchanges are consistent with .... nonracialism and opposition to apartheid . . reserving the right to protest against such exchanges which have the effect of legitimating and strengthening the apartheid system". This policy of selective support for academic exchanges is now more relevant than ever.

I have personally always opposed the academic boycott, which I believe has done more harm than good (in which respect I have always made my opposition to the policy of the Association of University Teachers quite clear to my colleagues on the executive committee). I understand that the former South African AUT (located in the 'open' universities) has now merged with the UDASA, as has the Witwatersrand Staff Association. I am glad to say that the AUT has now recognized UDASA. It follows from this that the academic boycott should be lifted, subject to the qualifications of the ANC.

JOHN GILLARD WATSON

11 Beaumont Buildings,

Oxford OX1 2LL, UK

SIR-The interpretation put upon the origin by country of letters published in Nature by J. F. Lamb $(\mathbf{3 4 3}, 404 ; 1990)$ is only one of several. Could we not equally surmise that the recent increase in letters from the United States may reflect better science now emanating from that area, rather than a worsening of that in the United Kingdom? As current figures reflect population numbers, should we not rather congratulate ourselves that lower levels of support here produce science that is equal to that of the United States, as judged by the Nature criterion?

Further, the sacred spectre of editorial judgement has not yet been raised. Could the opening of the Japan office of Nature have anything to do with the increase in that country's representation? Assuming only fine differences exist between some papers that are accepted or rejected, perhaps in those cases editorial decisions are inevitably influenced by country of origin? Could there even be a quota, unconscious or otherwise? Finally, does the huge increase in physics papers from West Germany, unremarked by the author, reflect increased funding levels by that country compared to others? If so, this might be a better illustration of a direct correlation between funding and publication in Nature.

P. J. BARNARD

MRC Molecular Neurobiology Unit, Hills Road, Cambridge CB2 $2 Q H$, UK

\section{Schrödinger}

SIR - May I add some information about Schrödinger (see Nature 341, 193, 1989; 337; 1989 and 343, 686; 1990)? On the occasion of Schrödinger's seventieth birthday in 1957, I (then Science Editor) wrote an article about his work and life for the Viennese newspaper Arbeiter-Zeitung after interviewing him at his home. As I wanted to be sure that my article was correct, I sent him the manuscript. He made some corrections which he explained in his covering letter of 24 July 1957 (which I donated to the Austrian National Library) and wrote also:

"... I would like very much to have the word Nazi opponent [which I had used in my article] replaced by a better one. For I am very unpolitical. (Sehr gerne hätte ich das Wort Nazigegner durch ein besseres ersetzt. Ich bin nämlich sehr unpolitisch - Schrödinger's emphasis) Nevertheless, I am for example 'an opponent' of assassins and sex murderers, sadists and murderers and arsonists. I remember clearly my three years in England (1933-36), when people listened to me willingly. But I felt that they thought in their hearts: 'Oh well, he is just from the other party, therefore, he rails. Would perhaps democrat or liberal do ... ??"

At the end of the letter he expressed his veiled sympathy for the Austrian Social Democrats of which ArbeiterZeitung was the party newspaper:

With a few small alterations it will be a nice birthday greeting with which I will be cordially pleased, from a side which among all [the last two words added later] in any case is nearest to me." 